\title{
Starbucks and Conservation International: How a sustained NGO- company partnership led to the coffee industry's first sustainability standard
}

Matthew McFall

Carolyn Rodehau

David Wofford

\section{Recommended Citation}

McFall, Matthew, Carolyn Rodehau, and David Wofford. 2017. "Starbucks and Conservation International: How a sustained NGO-company partnership led to the coffee industry's first sustainability standard," case study. Washington, DC: Population Council, The Evidence Project. 


\title{
Starbucks and Conservation International
}

\author{
How a sustained NGO-company partnership led to the coffee industry's first \\ sustainability standard
}

In 1999, Starbucks and Conservation International (Cl) launched a partnership that not only helped to change the Starbucks business model for sourcing coffee but reverberated throughout the coffee industry. The partnership was an example of business and environmental interests coming together to have a major impact on policies and practices governing commodity production (in this case, of coffee). It also demonstrated the scale of impact that can be achieved through a long-term investment and a deep, sustained working relationship between a company and an NGO. A pair of small scale initiatives with $\mathrm{Cl}$ in Costa Rico and Mexico eventually led to the development of Starbucks' own tailor-made coffee standard - Coffee and Farmer Equity (C.A.F.E.) Practices - through which Starbucks now sources 99 percent of its coffee, benefiting over a million coffee farmers worldwide (Conservation International 2017).

Starbucks did not start out with a deep commitment to either ethical sourcing or the environment. Prior to the $\mathrm{Cl}$ partnership, Starbucks had no experience in setting environmental standards. It had previously purchased Fair Trade coffee but had not participated in the creation of the certification (Perez-Aleman et al. 2008). For Starbucks, Fair Trade was a type of coffee, not a business model - Fair Trade-certified coffee was just one of a several varieties it offered. Fair Trade certification is meant to provide farmers and agricultural workers in developing countries better prices,

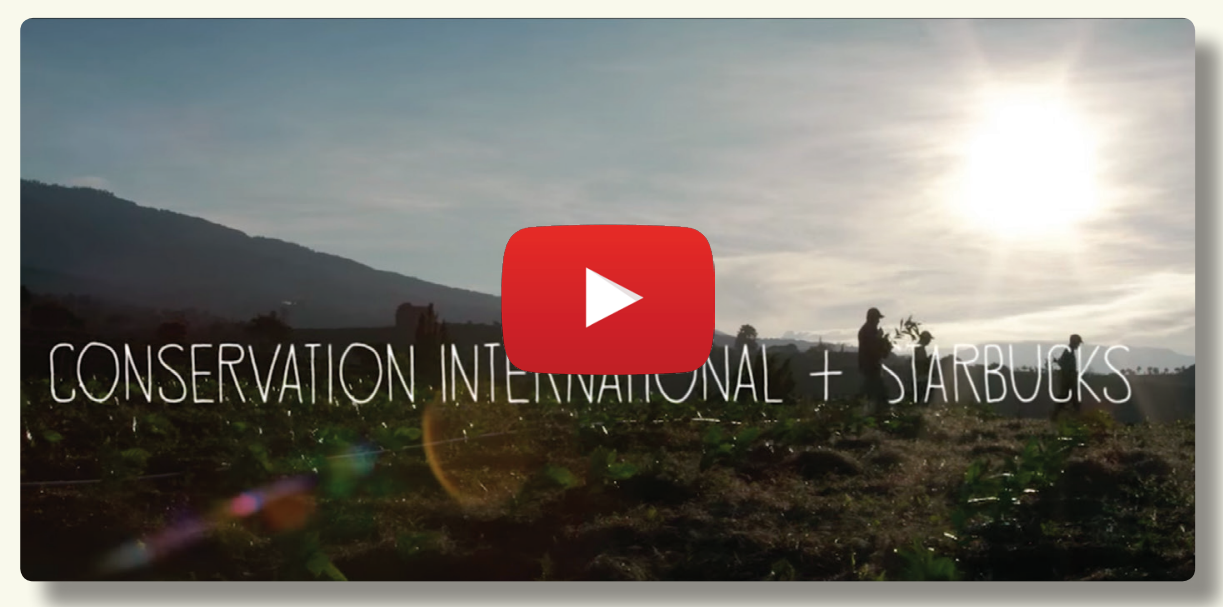

stable market access and resources for social and environmental projects, while giving consumers an option to support poor farmers by purchasing products that uphold defined social and environmental standards. Yet the Fair Trade system did not focus on ensuring the quality of coffee and therefore did not align closely with Starbucks'

This case study is part of a broader analysis on key lessons women's health advocates can learn from the environmental movement on effective strategies for driving changes in corporate policies and practices. To read the full brief and other case studies, go to http://evidenceproject.popcouncil.org/?p=3034. 
mission to be the "premier purveyor of the finest coffee." The company, in fact, was ambivalent about Fair Trade, identifying it as an issue that was important to external stakeholders, but not to the company (Raynolds 2008).

In the mid-1990s, when activists began pressuring Starbucks to support more sustainable coffee supply chains, the company responded reactively by creating a supplier code of conduct focused primarily on labor and occupational health and safety issues. Ensuring a reliable, high quality supply of coffee beans remained among the company's main concerns, as it was buffeted by a major coffee production crisis in the late 1990s and the dramatic fall in world coffee prices from 1998-2002. Starbucks did increasingly recognize the growing vulnerability of its supply chain in coffee producing regions to climate change, as well as the impact of coffee production on deforestation and other environmental harms. With this recognition, it saw the need to incorporate environmental and social sustainability criteria into its coffee sourcing policies to ensure long-term quality and a secure supply of beans (Perez-Aleman et al. 2008).

The partnership with Conservation International in 1997 sought to develop ethical sourcing guidelines for Starbucks' coffee that promote environmentally- and sociallysound growing practices. They focused initially on coffee producers in Chiapas, Mexico, where $\mathrm{Cl}$ was working with farmers on implementing shade-grown coffee practices that could improve quality, increase production, and improve environmental performance. Because $\mathrm{Cl}$ had experience working directly with small coffee producers on Conservation Coffee projects, the partnership enabled Starbucks to learn more about its own supply chain and the conditions of small-scale farmers at the bottom of the pyramid, which represent a majority of its suppliers (Perez-Aleman et al. 2008). The project in Chiapas, through multi-stakeholder efforts, spawned the development of Conservation Principles for Coffee Production in 2001, and Starbucks became the first company to follow these principles (Perez-Aleman et al. 2008).

FIGURE 1. STARBUCKS' C.A.F.E. PRACTICES

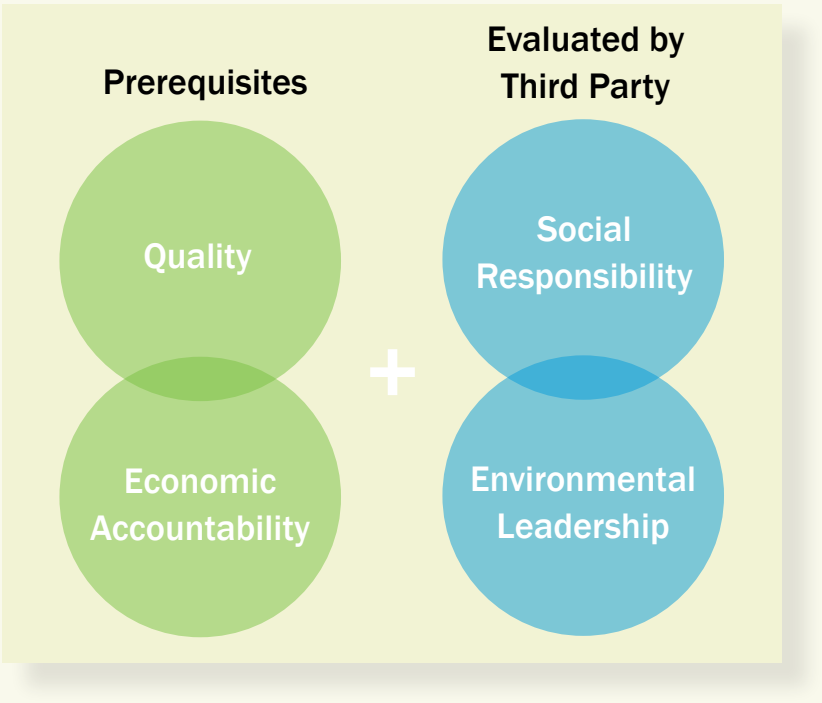

Building on the success of their work in Chiapas, $\mathrm{Cl}$ and Starbucks created the C.A.F.E. Practices standard, which has four overarching themes (see Figure 3), with multiple criteria and sub-indicators. The standard has much in common with other, more recent commodity-focused standards in terms of the social and environmental issues it covers, with some coffee-specific criteria based on particular processing and growing techniques. It is notable that the C.A.F.E. standard, like most global standards and certifications, lacks a gender-specific component or lens, and coverage of worker health is limited, with no mention of women's health specifically (Starbucks 2017).

To help small producers meet the new C.A.F.E. standards, Starbucks began investing in training farmers on better management practices, opening

a Farmer Support Center in Costa Rica to work directly with farmers in Central America and Mexico so they could meet the C.A.F.E. standard. The establishment of this center represented an investment in a hands-on approach to assisting farmers achieve sustainability in the coffee supply chain. This approach is different from other certification programs and standards, which typically include an audit process by 
independent or "third party" auditors that farmers can fail if they do not meet the standard. This compliance model has been criticized as promoting the policing of supply chains rather than continuous improvement. The C.A.F.E. approach is more akin to a counseling session on how farmers can improve to meet the standard. If farmers are doing something wrong, the Starbucks team tells them how they can improve, but the company still purchases their coffee (Charles 2013). There are however, some indicators within the standard that have a "zero-tolerance" approach, on issues such as minimum wage, child labor, forced labor, and deforestation, meaning that if these basic criteria are not met, a farmer would not be certified.

If C.A.F.E. practices were enforced through a more conventional third-party certification process, farmers that did not meet the standard would not be certified, and Starbucks would not be able to purchase coffee from that farmer. The loss of Starbucks' business would harm small farmers who may be working hard, but falling short, to meet standards that allow their coffee to be labelled as ethically- or sustainably-sourced. Compliance standards in which the primary recourse is to drop those suppliers can have the unintended consequence of excluding small-scale and poorer producers from the supply chain if they cannot afford the investments necessary to become compliant. By owning the standard, Starbucks can simultaneously support farmers' livelihoods by purchasing their coffee, while working with them to achieve C.A.F.E. and improve their production practices over the long term.

A crucial factor in this approach is the commitment to active assistance, both financially and technically, for its suppliers to meet the C.A.F.E. standard. Starbucks incentivizes its suppliers to adopt and upgrade their production standards through financial mechanisms that go beyond the conventional price-premium for farmers that meet the standard. It also provides an assured market for its suppliers through longer-term contracts, which reduces uncertainty for suppliers and increases the value attached to improving their production practices. By investing in this approach, Starbucks is also able to guarantee traceability and transparency for its coffee sourcing, reducing risk and ensuring a long-term, secure supply (Perez-Aleman et al. 2008).

TABLE 1. STARBUCKS' INCENTIVES FOR FARMERS TO ACHIEVE HIGH CAFE STANDARDS (LEE 2008)

\begin{tabular}{|c|c|c|}
\hline Compliance Rate & Result & Benefit \\
\hline $60 \%$ or more & Preferred supplier & $\begin{array}{c}\text { Preference in future SBX } \\
\text { purchases }\end{array}$ \\
\hline $80 \%$ or more & Strategic supplier & $\begin{array}{c}\$ 0.05 \text { per pound price } \\
\text { premium }\end{array}$ \\
\hline $\begin{array}{c}10 \% \text { improvement on } \\
80 \% \text { in one year }\end{array}$ & Additional price premium of $\$ 0.05$ per pound \\
\hline
\end{tabular}

Ilt is important to note that the C.A.F.E. system works in large part due to the unique characteristics of the coffee sector, where there is a premium placed on quality, a highly differentiated market, and a large share of smallholder producers. For other, more uniform bulk commodities, such as soybeans, palm oil, or maize, this system may not be as effective, since the product cannot be differentiated by quality and taste, and large agribusinesses dominate the market. It is also important to note 
that while Starbucks produces and sells products other than coffee, coffee is at the forefront of its business and brand and therefore, for the company to be serious about sustainability, it has to focus primarily on coffee. The approach to sustainability taken by World Wildlife Fund and other NGOs with McDonald's echoes the $\mathrm{Cl}$ and Starbucks approach - for McDonald's to demonstrate its seriousness in addressing sustainability, it has to focus first and foremost on its beef supply chain. For other companies with more diversified product portfolios, justifying the level of investment Starbucks has made into its coffee supply chain may be more challenging if the company is only a small player in a variety of markets.

The partnership with $\mathrm{Cl}$ enabled Starbucks to engage local public and private organizations to design standards and define implementation strategies that address the specific conditions and challenges facing small-scale suppliers in developing countries. Local organizations helped develop new norms for environmentally-friendly coffee production, beginning with Mexican universities, government agencies and the Bank of Mexico in the initial Chiapas pilot project. This approach was continued when the Farmer Support Center was opened in Costa Rica in 2004, and Starbucks continues to work closely with local actors and directly with farmers through its C.A.F.E. program.

The Starbucks-Cl partnership is an example of a collaboration that transformed into a more intense alliance involving collaboration on internal corporate processes and product development. Both Starbucks and $\mathrm{Cl}$ agree that the alliance between the two organizations progressed successfully because it not only focused on environmental and social issues, but also aligned with Starbucks' business structure (Rondinelli et al. 2003). Such an intense partnership is not necessarily possible for all NGO-business relationships or initiatives, but may be a model for companies whose business and brand revolves around a single commodity or product.

The Starbucks-Cl partnership has enabled $\mathrm{Cl}$ to form additional partnerships on conservation with local actors in coffee-sourcing regions, while also enabling significant donor and in-kind financial investments and government commitment in Starbuckssourcing regions, including a grant to $\mathrm{Cl}$ from the Global Environment Facility in 2010 to expand and scale up its initiative to 10 additional watersheds in Chiapas (Kissinger et al. 2015).

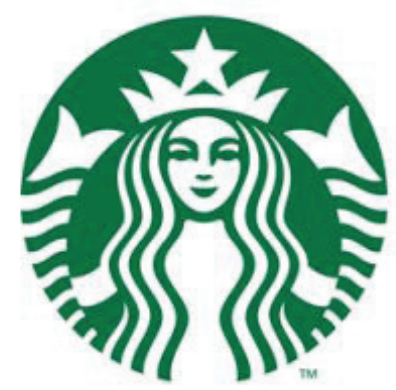

CONSERVATION INTERNATIONAL.

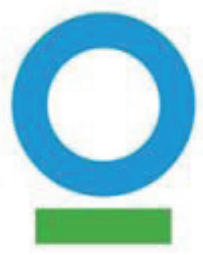




\section{REFERENCES}

Charles, Dan. 2013. “Coffee For A Cause: What Do Those FeelGood Labels Deliver?” http://www.npr.org/sections/thesalt/2013/04/24/177757797/coffee-for-a-cause-what-do-those-feelgood-labels-deliver. Accessed March 302017.

Conservation International. 2017. “ Follow Starbucks' 15 Year Journey to 100\% Ethically Sourced Coffee.” http://www.conservation.org/partners/ pages/starbucks.aspx Accessed March 302017.

Lee, Hau L. “Embedding Sustainability: Lessons from the Front Line.” 2008. International Commerce Review 8, no.: 10-20. doi:10.1007/s12146008-0026-4.

Kissinger, Gabrielle, Andre Brasser, and Lee Gross. 2013. “Scoping study. Reducing Risk: Landscape Approaches to Sustainable Sourcing." Landscapes for People, Food and Nature Initiative. http://peoplefoodandnature.org/wp-content/uploads/2013/04/ReducingRisk SynthesisReport_2013.pdf. Accessed January 302017.

Langert, Bob. 2016. “The 10 commandments for sustainability collaborations." https://www.greenbiz.com/article/10-commandments-sustainability-collaborations. Accessed March 302017.
Perez-Aleman, Paola, and Marion Sandilands. 2008. “Building Value at the Top and the Bottom of the Global Supply Chain: MNC-NGO Partnerships." California Management Review 51, no. 1: 24-49. doi: 10.2307/41166467

Raynolds, Laura. 2009. “Mainstreaming Fair Trade Coffee: From Partnership to Traceability." World Development. Vol. 37, No. 6, pp. 1083-1093, 2009 doi:10.1016/j.worlddev.2008.10.001

Rondinelli, Dennis A., and Ted London. 2003. "How Corporations and Environmental Groups Cooperate: Assessing Cross-Sector Alliances and Collaborations." The Academy of Management Executive 17, no. 1: 61-76. doi: 10.5465/AME.2003.9474812

Starbucks. 2017. “Ethical Sourcing: Coffee." http://www.starbucks.com/ responsibility/sourcing/coffee. Accessed March 302017.

\section{THE EVIDENCE PROJECT}

Population Council 4301 Connecticut Avenue NW

Suite 280

Washington, DC 20008 USA

tel +12022379400

evidenceproject@popcouncil.org
The Evidence Project is made possible by the generous support of the American people through the United States Agency for International Development (USAID) under the terms of cooperative agreement no. AID-OAA-A-13-00087. The contents of this document are the sole responsibility of the Evidence Project and Population Council and do not necessarily reflect the views of USAID or the United States Government.

Evidence

The Evidence Project uses implementation science-the strategic generation, translation, and use of evidence-to strengthen and scale up family planning and reproductive health programs to reduce unintended pregnancies worldwide. The Evidence Project is led by the Population Council in partnership with INDEPTH Network, International Planned Parenthood Federation, PATH, Population Reference Bureau, and a University Research Network.

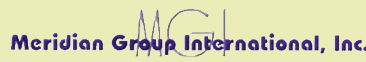

Meridian Group International, Inc. is a woman-owned, small business that works with the private and public sectors to create innovative programs and partnerships that benefit both business and society. Meridian Group International, Inc. is a partner of the Evidence Project and the Cambodia Worker Health Coalition.

Suggested Citation: McFall, Matthew, Carolyn Rodehau, and David Wofford. 2017. "Oxfam's "Behind the Brands" Campaign," Case Study. Washington, DC: Population Council, The Evidence Project.

(c) 2017 The Population Council, Inc. 